\title{
A PRELIMINARY ANALYSIS OF INOVAR AUTO IMPACT ON THE BRAZILIAN AUTOMOTIVE INDUSTRY R \& D ACTIVITY
}

\author{
Adriana Marotti de Mello \\ Doutora em Engenharia de Produção pela Escola Politécnica da Universidade de São Paulo - USP \\ Professora Doutora da Faculdade de Economia, Administração e Contabilidade da Universidade de \\ São Paulo - USP \\ adriana.marotti@usp.br (Brasil)
}

\section{Roberto Marx}

Doutor em Engenharia de Produção pela Escola Politécnica da Universidade de São Paulo - USP Professor Associado da Escola Politécnica da Universidade de São Paulo (Departamento de Eng.Produção) - USP

robemarx@usp.br (Brasil)

\section{Flavia Gutierrez Motta}

Doutora em Engenharia de Produção pela Escola Politécnica da Universidade de São Paulo - USP Gerente Coordenadoria de Planejamento e Negócios - Instituo de Pesquisas Tecnológicas - IPT flagumotta@ipt.br (Brasil)

\begin{abstract}
Aiming to increase the competitiveness, technology and security of vehicles produced and sold by the Brazilian Automotive Industry, in 2012 the Brazilian Federal Government established the "Inovar Auto" by executive law. Given the relevance and scope of the Inovar Auto Law, this paper aims to conduct a review of the preliminary results already obtained by different companies that joined the program. Therefore, through interviews with governmental agents, R \& D managers, as well as R \& D public and private centers representatives, we intend to analyze the quantity and quality of R\&D projects developed by the Brazilian automotive industry, with or without an external partnership, analyzing how Inovar Auto Law has influenced this result. The interviews and data presented herein suggest that the program is very promising as regards the increase in number and in quality of the R\&D activities developed by assemblers, systemists and ISTs connected to the automotive chain and particularly to the energy efficiency aspects highlighted in the program.
\end{abstract}

Keywords: Automotive Industry; Innovation; Public Policies. 


\section{INTRODUCTION}

Aiming to increase the competitiveness, technology and security of vehicles produced and sold by the Brazilian Automotive Industry, in 2012 the Brazilian Federal Government established the "Inovar Auto" by executive law. It is an industrial policy that provides tax reduction benefits to assemblers that meet or exceed certain goals.

Overall, the objectives involve (Ibusuki et al, 2014):

- A minimum number of productive activities conducted in the country (mandatory for all companies intending to adhere to the program)

- Improvement in energy efficiency indicator, measured in $\mathrm{CO} 2$ emission/fuel consumption (mandatory for all companies intending to adhere to the program) ${ }^{1}$

Additionally, each company has to choose two of the following three objectives:

- A minimum percentage of investment in R \& D

- A minimum percentage of investment in Engineering

- Adherence to the national program of vehicle labeling related to energy

efficiency

The program is valid for the period 2013-2017 and will be reviewed at its end.

During this period, companies are encouraged to continuously improve the objectives expected to maintain tax reduction benefits over the period.

Theoretically, the program has been considered the most comprehensive andwell designed of all previous incentive initiatives established for the sector. Although companies may be considered to be still adjusting their policies in order to meet the program goals, it should be emphasized that by 2014, about 44 assemblers (which already have operations in Brazil and others that plan to do so) had already joined the program, aiming to make use of the benefits offered.

As in all industrial policies, the results are not necessarily those initially expected. Thus, given the relevance and scope of the Inovar Auto Law, this paper aims to conduct a review of the preliminary results already obtained by different companies that joined the program. Our focus is to analyze the quantity and quality of $R \& D$ projects developed by the Brazilian automotive industry, with or without an external partnership, analyzing how Inovar Auto Law has influenced this result.

\footnotetext{
${ }^{1} 1$ It is worth highlighting the fact that as from March 2015, hybrid, electric and hydrogen cell cars sold in the country will receive an additional incentive in the calculation of the energy efficiency indicator used by Inovar Auto rules.
} 
Therefore, through interviews with governmental agents, R \& D managers, as well as R \& D public and private centers representatives, we intend to identify:

1) To what extent new investments were made as a result of the Inovar Auto Law or were already planned by companies even without this kind of stimulus.

2) What the nature of those investments is: what the focus of the projects is, investments planned, if engineers and technicians were hired to do so.

3) To what extent Inovar Auto Law could impact the consolidation of R\&D activities in Brazil or at least the establishment of a consistent strategy for firms.

4) What role do the public and/or private Institutes of Science and Technology (IST) play in this context.

In order to answer those questions, we conducted a multiple-case study in automakers and suppliers, R\&D centers and governmental agents that are somehow involved with Inovar Auto Law. We conducted in-depth interviews with managers and/or other executives responsible for innovation projects.

In general, our objective is to contribute to the analysis of the effectiveness of industrial policies aiming to increase competitiveness and to consolidate production value chains in countries with features similar to those in Brazil, i.e. with large market, production facilities and expertise, but with few or non-existent $R \& D$ and facing fierce global competition. We also intend to provide a critical analysis of the program, as well as some recommendations on how to improve the program in its possible continuation after 2017.

The article is organized as follows. In section 2, the conceptual basis of the study is synthesized. Section 3 presents the research methodology, and section 4 presents the results of the interviews conducted. Finally, in sections 5 and 6, results are discussed and conclusions are presented, pointing out some study limitations and suggesting further research. 


\section{CONCEPTUAL BASIS}

\subsection{R\&D Profile for the Automotive Sector in Brazil and the Inovar Auto Law}

The automotive industry has proven over the years to be an important source of economic and social development to several countries as it generates employment, income, capital investments and thus contributes to short and long-term growth.

However, this sector is even more crucial to developing countries such as Brazil inasmuch as their economies are not as diversified as the developed ones. The figures below support the latter statement: 23\% of the Brazilian Industrial Gross Domestic Product (GDP) in 2013 relied only on the automotive industry. Additionally, it is accountable for generating 1.5 million jobs. Brazil is the 7 th major producer and the $4^{\text {th }}$ largest market (ANFAVEA, 2015).

However, unlike other emerging countries, such as China and Korea, Brazil has no actual national automotive industry: all automakers that produce locally are subsidiaries from foreign multinationals, and most of the first tier suppliers are foreign companies. Despite its foreign origin, the industry was able to develop competencies in engineering and product development throughout its trajectory here started in the 1950s (Salerno et. al, 2009).

Currently, the country has qualified engineering centers, capable of designing a new vehicle from concept definition to product and process validation; but those competencies are still concentrated in the traditional automakers, also called "latecomer companies". And most of the innovation efforts are driven to adapting global models to local market conditions. (Castro et. al. 2014, Souza e Mello, 2014).

Latecomer companies in Brazil should not have difficulties in achieving the minimum percentage of investments in $R \& D-0.5 \%$. The same cannot be said about newcomer companies, mostly Asian companies, which bring all the vehicle concept, project and process developed and only assemble it here (Ibusuki et.al, 2014). The automotive industry still invests more in innovation than the average of thedomestic industry: The 2011 National Innovation Survey (PINTEC) showed that theBrazilian Transformation industry on average invested just $0.72 \%$ of their net revenuein $R \& D$, while automakers invested $1.39 \%$ and autoparts producers, 1.17\%. (Castro et.al.2014, Souza e Mello, 2014).

Revista de Administração e Inovação, São Paulo, v. 13, n.1, p. 47-62, jan./mar. 2016. 
As mentioned above, the automotive industry in Brazil experienced a steadily growthin production and sales over the last decade, but this growth was not proportional to the growth in $\mathrm{R} \& \mathrm{D}$ expenditure, as shown in Figure 1. ${ }^{2}$

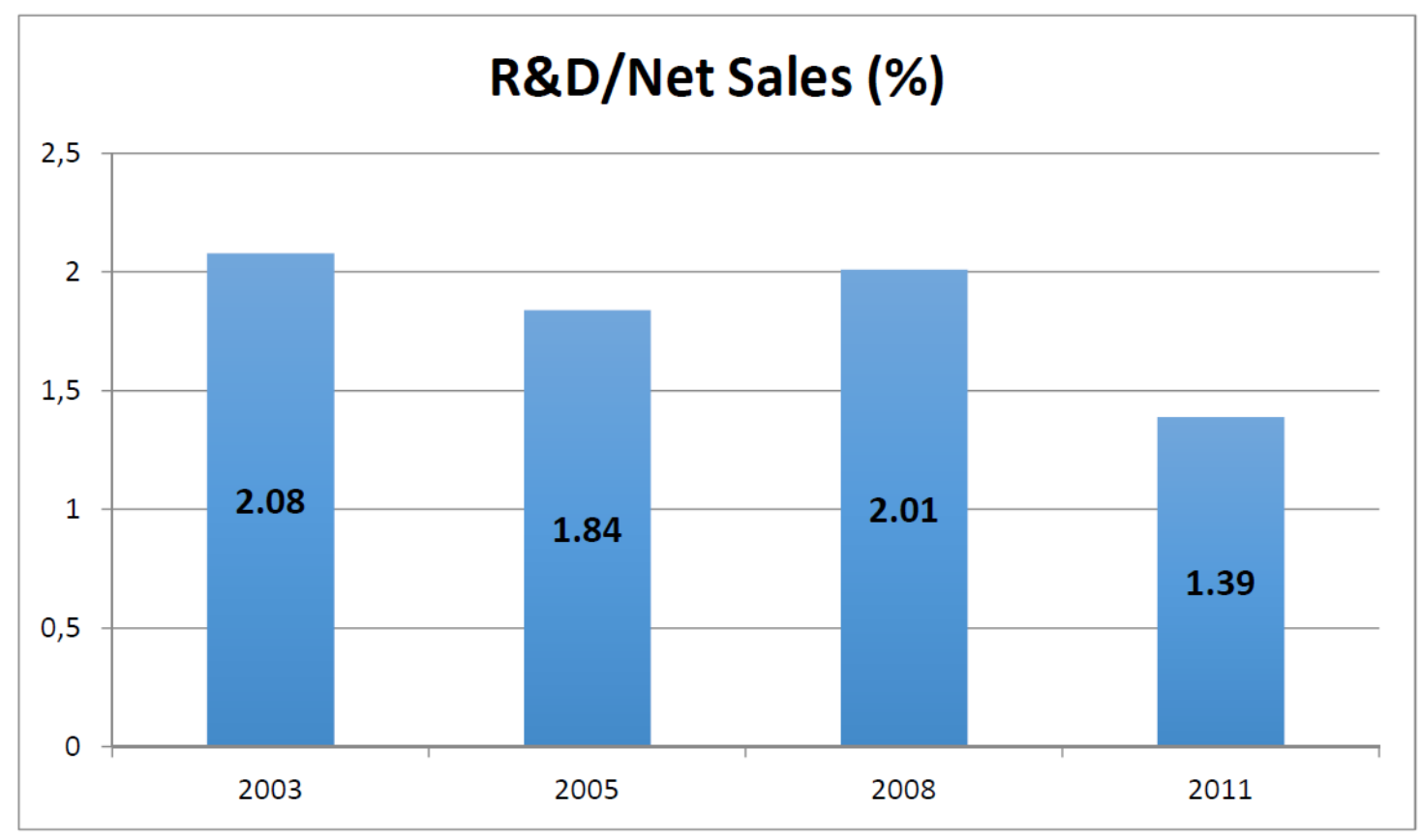

Figure $1-\mathrm{R} \& \mathrm{D} / \mathrm{Net}$ Sales from Automakers in Brazil.

Source: Elaborated by the authors, with data from Souza and Mello (2014)

The Inovar Auto Law initiative intends to deal exactly with this point: attract more R\&D and Engineering investments to modernize products and raise local content and, consequently, to create more and sophisticated jobs and income at a macroeconomic level. This paper discusses the results and bottlenecks raised so far.

\subsection{Effectiveness of Public Policies regarding Innovation}

The very existence of public initiative concerning its role on competitiveness in general and in innovation in particular is currently very widely recognized. Differently from a couple of years ago, the discussion is now concentrated in what the characteristics and nature of relevant public action

\footnotetext{
${ }^{2}$ R\&D expenditures definition for Inovar Auto could be more restrictive that those in Pintec (Innovation Survey) .
} 
would be concerning incentives and subsidies to firms so as to improve - in the long term competitiveness and innovation. Lascoumes and Le Gales (2007) illuminate another point of view, stressing the symbolic and agenda orientation sides that public policies influence and conform to(sometimes unintentionally).

In the last 12 years, a myriad of public policies was proposed by the Federal Government, with different tools and oriented to different industries. In many cases, the initial goals were not pursued and the agenda of competitiveness and innovation results was far from be completely achieved. In the case of the Inovar Auto Law, it ispossible to point out at least two different characteristics:

1) The focus is on raising energy efficiency; hence, the innovation is oriented to this specific form of product innovation

2) The type of other investments in R\&D that may be considered to give access to subsidies is much more precise if compared to previous initiatives such as the so-called "Innovation Law" (from 2004).

Moreover, as Lascoumes and Le Gales propose, the symbolic aspect of the Inovar Auto Law program is also important; assemblers in particular and the automotive chain in general started to discuss very specific details, what $\mathrm{R} \& \mathrm{D}$ is and what it is not, what the difference is between Engineering and R\&D. Since 2015, every assembler interviewed has asked what can be done to raise energy efficiency and, where the competences are to allow bringing some innovation to the product and components sold in the country.

For the first time in Brazil, this new agenda may enable the real consideration of partnerships among the automotive industry and academic laboratories, research institutes and even between assemblers and first tier companies. As we will describe later in this paper, this type of initiative was labeled Open Innovation by Chesbrough,(2003a). This concept and its application to the automotive industry are discussed in some more detail in the next item.

\subsection{Open Innovation in the Automotive Industry}

"Open innovation implies that firms increasingly rely on external sources of innovation by emphasizing that ideas, resources and individuals flow in and out of organizations" (Chesbrough, 2006). Chesbrough differentiates between two kinds of Open Innovation: inbound, in which new ideas flow into an organization, and outbound, in which unused/unusual technologies can be acquired by 
external organizations with business models that are better suited to commercialize a given technology (Chesbrough and Crowther, 2006).

The authors cited above conclude that, concerning the automotive industry, it predominantly uses its own R\&D and its direct environment as a means to innovation. Customers are the most important source for innovation, followed by competitors and suppliers. Governmental regulations are an additional source for it.

Ili et al. (2010) corroborate those conclusions - in a research conducted with 42 German automotive companies (five OEMs), they found evidence that the Open Innovation model is suitable to the automotive industry, but a tendency toward a closed innovation paradigm still prevails.

This conclusion is valid for what seems to happen in this industry, but it is important to stress that, in the Brazilian case, local product engineering competencies have grown since the late 1990s. Yet product innovation competencies, budget and decisions are still concentrated in the companies' headquarters. Governmental regulations do seem to have fostered neither engineering nor innovation but most of these initiatives were directed to enhance production and sales. To what extent may the Inovar Auto Law change this scenario? Changing this scenario would mean - for the Brazilian Automotive industry - to foster collaboration among suppliers, research institutes and laboratories to work with engineering and product and process innovation at a higher intensity if compared with the current situation.

\section{RESEARCH METHOD}

To help answer the questions raised by this paper, the authors interviewed the following actors that are somehow involved in the design and implementation of the Inovar Auto Law:

- Industrial Policy makers

- Assemblers and first tier systemists representatives involved in R\&D and Engineering

- Managers and/ or coordinators of laboratories, research institutes (public and/ or private; inside or outside universities)

- Other institutional players somehow involved in the program

The criteria used for selection was mainly the knowledge we have about those actors and their involvement in efforts to design, to implement and to use the benefits of the program. It was, for that purpose, a directional choice based on previous information about the respondents. 
A checklist was used with a group of questions to guide the interview, as follows:

- Identification (name, firm, lab, etc.)

- Main collaboration with firms/ research labs/ others to develop innovation in products (resources involved, duration, division of labour)

- Comparison between before and after the Inovar Auto Law (what has changed so far)

- What can be considered bottlenecks that prevent collaboration to grow

- Suggestions to improve the program in a renewed version

With this strategy and points of interest, the authors could reach the following interviewees (names will not be mentioned as a compromise made with all respondents):

- 2 Consultant firm representatives that sell services that guide and organize processes to take advantage of R\&D and Innovation Public Initiatives, such as the Inovar Auto Law

- 1 public research institute that develops tests and provides services to various industries including the automotive one.

- 1 coordinator of a research group located at the University of São Paulo

- 1 technician that works for the BNDES (National Bank for Economic and Social Development), the main source of financial investment to all kind of industries in Brazil

- 3 OEMs representatives

- 1 first tier supplier representative that works in a research center located in São Paulo

\section{RESULTS}

\subsection{Inovar Auto Opportunities}

Inovar Auto Law is an opportunity for companies to benefit from the government incentives. The vehicle efficiency goal in Brazil is $1.82 \mathrm{MJ} / \mathrm{km}$ until 2017. This goal is based on Europe 2015 target for new LRVs (Light Road Vehicle) of $130 \mathrm{gCO} / \mathrm{km}$, and considering differences in driving cycle, vehicle, fuel, and road specifications. The Brazilian fuel efficiency target is not a technical challenge for the automotive industry as a whole since the technology is available in the headquarter countries (La Rovere et al, 2014).

The main opportunity opened the by Inovar Auto Law is the motivation for the automotive industry to internalize international technology decreasing the existing gap with Brazil. This task is a 
challenge considering the peculiar characters of the Brazilian market as compared to the assembler headquarters: the road conditions are substantially different from those in developed countries; Brazilian fuel characteristics are also different with a higher blend of ethanol in gasoline; and the main peculiarity is the flex engine. These conditions require additional developments and investments to adapt the technologies developed outside Brazil to work here.

Before the Inovar Auto Law, there was a wide gap regarding technological developments in developed countries. Companies postponed the internalization of technologies into the Brazilian market because of the costs involved. Regulations and requirements of the Brazilian market did not encourage bridging the gap. With the Inovar formal goal imposed for minimum energy efficiency standards, the internalization of technologies for powertrain systems and other accessories forreducing fuel consumption intensified. Examples are start-stop systems, tire pressurecontrol system, indicator of gear shift. The Brazilian investments in these technologies are made adapting materials and the components that come into contact with the flex engine fuel. The need to reduce the engine size and weight is also an attractive factor for companies to hire ISTs for developing new technologies in order to meet the demands of higher energy efficiency.

According to some interviewees, there was an anticipation of the 3-cylinder engines release based on the requirements of the Inovar Auto Law. The technology was totally adapted to the local conditions mentioned above. Overall, statistics do not clearly show these improvements in R\&D spending, and it is still early to connect them as a direct result of the Inovar Auto Law. Also, it is still early to talk about sustainable results, because the law has been in force for only three years. In 2014, the MCTI (Ministry of Science, Technology and Innovation) report stated that all assemblers had their $R \& D$ spending approved as a result of the uncertainties of $R \& D$ classification.

Nevertheless, the trend is clear, assemblers have sought more partnerships with their suppliers and ISTs to adapt and to absorb the technologies used in developed countries.

\section{2 "Lei do Bem"}

Before the Inovar Auto Law, the automotive companies had already used the tax incentives from "Lei do Bem" [Law of Good], which allows tax deduction for R\&D spending. The mechanical and transport industry represented $24 \%$ of the total value declared as tax deduction in 2014 , but this 
number had already doubled by $46 \%$ of the total in 2008. The Lei do Bem has been emphasized by companies interviewed in this research as the first significant step that helped to adapt the accounting system for registering R\&D expenditures regarding Inovar Auto Law.

In this context, the traditional automakers (those that started to produce in Brazil in the late 1970s) have been working with $R \& D$ and engineering, motivated by the strategies of their business to develop vehicles adequate to the Brazilian market. The R\&D Incentive Law and the Inovar Auto Law have represented strong arguments for subsidiary units to maintain and to intensify R\&D and engineering activities in Brazil.

\subsection{Corporate Strategy Issue}

According to the MDIC (Ministry of Development, Industry and Commerce), there was a total of 36 companies qualified in the Inovar Auto program in April 2015 (including manufacturer and importer qualifications). Considering that each organization would have to opt for 2 goals from the 3 existing alternatives, the present frame shows that:

19 companies opted for attaining the goals in $R \& D$

35 companies, for Engineering goals

26 companies, for Vehicle Labeling

Traditional companies (latecomers) have easily attained the rates of resource application to Engineering and to local content. The investments in $R \& D$ are made at different intensities by the assemblers. Some are far more aggressive than others as regards investments in R\&D.

The smaller the size and the number of development centers of assemblers in the world, the greater is the change in the projects being developed in the country.

The Lei do Bem has existed since 2006. The companies considered latecomers knew and benefitted from it. The newcomers have to understand it all at once now. It is worth highlighting that the Lei do Bem is still in force and that its benefits can be obtained by the same activities provided in Inovar Auto.The Newcomers (Chinese, Japanese, Korean and French) generally have moredifficulties with engineering and R\&D. For this reason, they have sought to study partnerships with systemists and research institutions/groups to attain the Inovar Auto goals.

A newcoming assembler opted for investing in engineering and in $R \& D$ for having difficulties in meeting the labeling requirements, for having the strategy to invest in local engineering, and even 
for managing to adapt their products to meet the energy efficiency goal, and lastly for the facility to meet the R\&D requirements in the short term by means of a network of partner ISTs.

Yet there are those that opt for labeling and engineering, once investments in R\&D are not a part of their strategy in Brazil.

Newcoming assemblers, focused on attaining the minimum rate of investment in $R \& D$, started to establish partnerships with ISTs to develop projects. This is a fast access path for conducting research for companies that do not count on installed structure in Brazil, but that intend to have one in the medium term. Only time will indicate the maturity, sustainability and the effective results of these relationships.

The latecomers' behavior, in turn, is not even. There are more aggressive companies, others that have done little so far in terms of taking more advantage from and of increasing the quantity and the quality of the R\&D initiatives. The most aggressive company introduced the following initiatives:

- It formalized a specific structure to account for the program, for the initiatives and procedures bonded to it. There is a group of 15 people (and a specific manager) in the different operations of the company in Brazil, in charge of assessing each investment project and of verifying whether it can fit the Inovar Auto program.

- Formal procedures were established to record the engineering and R\&D activities that may be considered for the effects of the program and, hence, facilitate and record these hours in the company accounting system.

- Substantial investments in laboratories and in partnerships with Brazilian universities to develop engineering applications formerly subcontracted abroad or developed in other company offices. According to the interviewees, these investments were made very attractive in Brazil after the benefits provided by Inovar Auto.

Other assemblers attributed a formal role to managers for them to administer Inovar Auto, yet they were not provided with a specific structure as in the previous case. The formalization of structures directed to Inovar Auto may be considered a proxy of the attention and benefit expected to be obtained from the program.

\subsection{The role of ISTs}


The number of consultations and of projects that have been contracted with research Institutions by the Brazilian Automotive Industry has considerably increased in recent years. However, there are not systematized quantitative data about the companies' investments stimulated by Inovar Auto. The ISTs claim to have received a larger number of requests for providing technological services and R\&D projects.

Part of the partnerships between ISTs and assemblers identified in this survey already existed before Inovar Auto; yet it cannot be denied that even the long-existing ones, were intensified and expanded with the legislation. Partnerships established after Inovar Auto were also identified. The Inovar Auto program has generally increased the number of company engineers who contribute to increasing the energy efficiency in graduate programs connected to the ISTs that assemblers and systemists partner with. Companies have sought ISTs to expand the response capacity of assemblers faced with the necessary developments, mainly in capacity building areas, which complement their R\&D structures and their own engineering.

One of the assemblers interviewed reported that it opted for conducting the more technical developments internally, and externalized to institutions in its development network the understanding and market trends projects, expanding the knowledge of consumer habits, and other technical issues that need intense knowledge, but are not considered the company core (acoustics, development of new materials, among others). These projects are developed by the ISTs and the knowledge/technologies are absorbed and later transformed into products and systems.

Another role played by ISTs is rendering technological services. These services were rendered by the headquarters in their country of origin; however, to reach the investment rates in Brazil, the companies have intensified the quest for their nationalization.

In a recent past, an opinion prevailed in that academic research laboratories in Brazilian universities were too theoretical and would not be interested in or capable of establishing partnerships with companies. This opinion was not confirmed in any assembler or systemist interviewed, which demonstrates there are ISTs capable of materializing technological development projects stimulated by the program under analysis.

A point of intense discussion for assemblers in their negotiations with ISTs is the intellectual property issue. The sensitive point regards the payment of additional remuneration for a company's exclusive exploration in the market of the potential patent resulting from researches agreed upon with the ISTs.

The cases with greater complexity as regards intellectual property are those of R\&D projects directed to productive processes. Some companies understand that, for having invested in the project 
development, for the result being for the company to use (and, therefore, not being a new product in the market that generates new resources), remuneration should not apply to the institution that provided the knowledge and generated a patent. Conversely, the ISTs expect an additional payment for the technology success. These negotiations may reach such an impasse that the project development is stalled.

Some partnership cases did not bear fruits because of this aspect; nevertheless, in other cases, difficulties were overcome after a certain amount of negotiation and of bridging divergences. Flexibility and understanding the restrictions of the parties are essential to solving these issues.

\subsection{Opportunities for improving Inovar Auto}

For the long term, the main point is improving the regulation. This legislation managed to reduce the technological gap in different technological areas, providing conditions to develop unprecedented R\&D activities, both in quantity and in quality, especially those approaching the needs of adapting engines to ethanol fuel, in the energy efficiency context.

Problems in understanding what can or cannot be considered R\&D expenses still remain. These doubts were much greater in the beginning but have largely been reduced, with the aid of AEA (the Automotive Engineers Association, which provides technical support and training in the area) and of a private consultancy specializing in fiscal benefits. This support was repeatedly mentioned as fundamental to make Inovar Auto clearer and to better guide the companies actions. Structuring a group with representatives from the government, from AEA, from the consultancy and from the companies to follow up and to adjust may be considered a recommendation to make viable future actions with a magnitude similar to that of Inovar Auto.

The cycle considered in the first stage of Inovar Auto (2013-2017) has been considered too short. More ambitious and longer term projects eventually do not fit the span of time established for this stage which has no guarantee of continuity. It would be important for a new version of the legislation to incorporate this modification, with medium and long-term goals; signalizers would be important for directing the sector efforts.

Another point is how to improve the use of the FNDCT (National Fund for Science and Technology Development) for the automotive sector. Currently, the companies that opt for investing in R\&D invest the resources directly in that fund. These resources could be reverted into researches for the sector, as occurred with the Petroleum \& Gas sector, CT-Petro. Currently, the use of the FNDCT is 
known not to have a specific destination, but it may come to be used, for example, as from bid notices for developing certain technologies that allow increasing the energy efficiency provided by Inovar Auto.

The smaller-sized autoparts manufacturers are out of the Inovar Auto program and could also be stimulated to contribute by means of invitations/incentives made by the assemblers, besides support from the government and from the institutions in the sector.

\section{CONCLUSIONS}

The results of the Inovar Auto are just beginning to be perceived and, therefore, there are no numerical results to support more definitive conclusions. The interviews and data presented herein suggest that the program is very promising as regards the increase in number and in quality of the R\&D activities developed by assemblers, systemists and ISTs connected to the automotive chain and particularly to the energy efficiency aspects highlighted in the program.

In its first version (it is expected to be extended and improved in 2017), the program

underwent an understanding and adjustment stage which lasted almost 2 years. Only late in 2014 did it actually start to have its actions developed by the companies interested in adhering.

In a recent event involving participants from 5 assemblers operating in Brazil, there was a consensus that Inovar Auto came to stay and that the competitiveness of the Brazilian automotive chain depends on this program and on its next versions.

A point deserving attention and that may largely affect what has been said up to the moment the interviews were made is that concerning the present economic crisis. It may stall investments in the next cycles, reducing the growth and investment pace for the new projects.

This is a recurrent trend in the Brazilian automotive industry; in periods of crisis, most of the investments yielding results in the medium and long terms undergo cuts or are even frozen, independently of the benefit forecast. There are signs that this has already been occurring in several cases in the organizations and ISTs interviewed. It will only be possible to observe and to comment on the materialization or not of this more pessimistic vision for the future of Inovar Auto and of innovation in the automotive chain in some months, when the effects of the economic crisis on the organizations' investments are more concretely perceived.

Revista de Administração e Inovação, São Paulo, v. 13, n.1, p. 47-62, jan./mar. 2016. 


\section{REFERENCES}

Castro, B.H.R., Barros, D.C., Vaz, L.F.H.(2014) Panorama da engenharia automotiva no Brasil: inovação e o apoio do BNDES . BNDES Setorial, Vol.39, 155-196.

Chesbrough, H. (2006). Open Innovation. The New Imperative for creating and profiting from Technology. Boston: Harvard Business School Press.

Chesbrough, H., \& Crowther, A. K. (2006). Beyond high tech: early adopters of open innovation in other industries. R\&d Management, 36(3), 229-236.

Ibusuki, U.; Bernardes, R.C., Consoni, F. (2014) New Brazilian automotive industrial policy: analysis of the consequences for local R\&D based on new comer's strategies. International Journal of Automotive Technology and Management, 15(1), 43- 62.

Ili, S., Albers, A., Miller, S.(2010) Open Innovation in Automotive Industry. R\&D Management. 40 (3), 246-255.

Lascoumes, P. \& Le Gales, P. (2007). Understanding Public Policy through Its Instruments-From the Nature of Instruments to the Sociology of Public Policy Instrumentation. International Journal of Policy, Administration, and Institutions, 20, (1), 1- 21.

Lima, M.F.C., Silva. M.A.(2012). Inovação em petróleo e gás no Brasil: a parceria Cenpes-

Petrobras e Coppe-UFRJ. Sociedade e Estado. 27(1), 97-115

Marx, R., Mello, A.M. (2014). New Initiatives, Trends and Dilemmas for the Brazilian Automotive Industry: The case of Inovar Auto and its impacts on Electromobility in Brazil. International Journal of Automotive Technology and Management, 14, 138-157

La Rovere, E. L., Pereira Jr, A. O., Dubeux, C. B. S., \& Wills, W. (2014). Climate change mitigation actions in Brazil. Climate and Development,6(sup1), 25-33.

Salerno, M.; Zilbovicius, M. Marx, R.; Dias, A. V. C. (2009). The importance of locally commanded design for the consolidation of local supply chain: the concept of design headquarters. International Journal of Manufacturing Technology and Management. 16, 361-376.

Souza, I. O. F. ; Mello, A. M. (2014). Innovative Developments in the Brazilian Automotive Industry. In: 23rd Annual IAMOT Conference, 2014, Washington. Proceedings of 24th Annual IAMOT Conference. 
The date of receipt: 10/25/2015

The date of acceptance: 02/02/2016 